Piotr Czarny

\title{
Status posła, który jest użytkownikiem i autorem w serwisie internetowym Patronite ${ }^{1}$
}

\author{
Status of a Deputy who is a user and author of the Patronite website
}

All activities of Deputy - author of the Patronite website constitute non-parliamentary activity, which is only partly subject to copyright and related rights, and therefore affects the Deputy's right to receive parliamentary salary. The Deputy is subject to an obligation to notify such activity to the Marshal of the Sejm. Income, other financial benefits and donations, which Deputy registered as an author on the Patronite website receives from the patrons of this website, are subject to disclosure in the declaration of financial status and appropriate notification to the Register of Benefits. As a part of activities resulting from the status of author of the Patronite website, a Deputy may not directly or indirectly refer to his parliamentary mandate or use the title of deputy.

Keywords: Internet, position compatibility, mandate, Deputy, copyright

Wszystkie działania posła będącego autorem w serwisie Patronite stanowią aktywność pozaparlamentarną, która tylko częściowo podlega prawu autorskiemu i prawom pokrewnym, a zatem oddziałuje na uprawnienie posła do otrzymywania uposażenia poselskiego. Podlega ona obowiązkowi zawiadomienia Marszałka Sejmu. Dochody, inne korzyści majątkowe i darowizny, które autor zarejestrowany w serwisie Patronite będący jednocześnie posłem otrzymuje od patronów i mecenasów tego serwisu, podlegają ujawnieniu w oświadczeniu o stanie majątkowym i odpowiedniemu zgłoszeniu do Rejestru Korzyści. W ramach działań wynikających ze statusu autora w serwisie Patronite poseł nie może bezpośrednio lub pośrednio powoływać się na swój mandat parlamentarny oraz posługiwać się tytułem posła.

Słowa kluczowe: Internet, mandat, poseł, prawo autorskie

doktor nauk prawnych, starszy wykładowca -

Uniwersytet Jagielloński w Krakowie, Wydział Prawa i Administracji, Katedra Prawa

Konstytucyjnego, KRAKÓW, POLSKA •

piotr.czarny@neostrada.pl • https://orcid.org/0000-0002-6558-1075

\section{Zagadnienia wstępne}

1. Przedmiotem niniejszej opinii prawnej jest ocena prawna: statusu autora w serwisie internetowym Patronite w kontekście dopuszczalności aktywności w tym charakterze w okresie wykonywania mandatu poselskiego, wpływu tego faktu na prawo do uposażenia poselskiego oraz obowiązku podawania dochodów (korzyści majątkowych, darowizn) z tym związanych w oświadczeniu ma-

$1 \quad$ Opinia prawna w sprawie statusu posła, który jest użytkownikiem i autorem serwisu internetowego Patronite sporządzona 8 listopada 2019 r. na zlecenie dyrektora Biura Analiz Sejmowych; BAS-WAKiU-2100/19. 
jątkowym i Rejestrze Korzyści. Co prawda, pytania te zostały postawione przez konkretnego posła, to jednak sformułowano je w sposób ogólny, stąd też opinia nie została odniesiona tylko do jednostkowego stanu faktycznego. Udzielenie „indywidualnej” i jednoznacznej odpowiedzi wymagałoby wielu dodatkowych informacji (dotyczących m.in. prowadzenia działalności gospodarczej, skali aktywności autora oraz wysokości uzyskiwanego wsparcia).

W związku z treścią zlecenia opinia została ograniczona do zagadnień dotyczących funkcjonowania serwisu Patronite (określanego również jako portal Patronite.pl), a zatem może nie być adekwatna do podobnych serwisów internetowych.

Podstawą sporządzenia niniejszej opinii były przepisy ustawy z dnia 9 maja 1996 r. o wykonywaniu mandatu posła i senatora (t.j. Dz.U. 2018, poz. 1799), ustawy z dnia 4 lutego 1994 r. o prawie autorskim i prawach pokrewnych (t.j. Dz.U. 2019, poz. 1231), uchwały nr 26 Prezydium Sejmu z dnia 25 września 2001 r. w sprawie szczegółowych zasad i trybu wypłacania uposażenia poselskiego oraz odprawy parlamentarnej (niepubl.), innych ustaw szczególnych oraz ustalenia dotyczące charakteru i form działalności serwisu Patronite, dokonane na podstawie jego strony internetowej www.Patronite.pl, a w szczególności jego regulaminu².

2. Kwestią wstępną w niniejszej opinii jest ustalenie charakteru serwisu internetowego Patronite. Jak ogólnie wskazano w jego regulaminie: „Patronite to miejsce łączące ludzi z pasją i talentem, z ludźmi chcącymi ten talent finansowo (i nie tylko) wspierać. Patronite daje możliwość nawiązania stałej współpracy pomiędzy Patronem oraz Autorem, która pozwala na promowanie oraz wspieranie rozwoju kultury”. Co istotne, zgodnie z $\$ 2$ ust. 1 regulaminu: „Serwis jest platformą komunikacji umożliwiającą kojarzenie Użytkowników poszukujących wsparcia finansowego dla prowadzonej przez siebie Działalności (Autorów) oraz Użytkowników chcących takiego wsparcia udzielić (Patronów, Mecenasów)". Portal działa głównie w oparciu o przepisy ustawy z dnia 18 lipca 2002 r. o świadczeniu usług drogą elektroniczną (t.j. Dz.U. 2019, poz. 123, ze zm.).

$\mathrm{Na}$ wstępie należy też dodać, że właścicielem tego serwisu i jego operatorem jest Crowd8 - spółka z ograniczoną odpowiedzialnością z siedzibą w Warszawie. Ponieważ zgodnie z powszechnie dostępnymi informacjami spółka ta stanowi „własność krajowych osób fizycznych”3, w dalszej części niniejszej opinii pominięto problematykę zakazu prowadzenia przez posłów działalności gospodarczej z osiąganiem korzyści z majątku Skarbu Państwa lub samorządu terytorialnego (art. 107 Konstytucji RP).

3. Działalność serwisu Patronite stanowi formę tzw. finansowania społecznościowego (ang. crowdfunding), które jest rozumiane jako rodzaj pokrywania kosztów różnego rodzaju przedsięwzięć (projektów) przez społeczność, która już

2 https://patronite.pl/regulamin [dostęp 29 października 2019].

3 http://www.krs-online.com.pl/crowd8-sp-z-o-o-krs-1595427.html [dostęp 29 października 2019 r.]. 
jest lub zostanie wokół tych projektów w jakiś sposób zorganizowana. W założeniu określone ogólnie przedsięwzięcie (projekt) jest w takim przypadku finansowane głównie poprzez znaczną liczbę drobnych, jednorazowych wpłat dokonywanych przez osoby nim zainteresowane. Należy dodać, że Patronite to serwis, który realizuje model tzw. crowdfundingu subskrypcyjnego. Ogólnie idea jego działalności została opisana w następujący sposób: „Patronite łączy Autorów z osobami, które chcą wesprzeć ich pasję nie tylko dobrym słowem, ale i finansowo. Patroni wpłacają regularne, comiesięczne kwoty na konto Autorów, a Ci mogą je wykorzystać na potrzeby swojej działalności. Autorzy zyskują możliwość rozwoju, a Patroni - dostęp do wyjątkowych nagród, a także bezcenną świadomość realnego wspierania pasji innych"4.

4. Przechodząc do statusu autora, należy stwierdzić, że to w regulaminie serwisu zdefiniowano go jako każdego „Użytkownika Serwisu prowadzącego Działalność, który posiada Konto Autora" ( $\$ 1$ pkt 2). Działalność ta może mieć charakter artystyczny, sportowy, społeczny, ale może być to również każdy inny przejaw działalności Autora realizowanej „za pomocą Serwisu i zgodny z profilem Serwisu" ( $\$ 1$ pkt 4). Nabycie statusu autora wymaga zgłoszenia operatorowi zamiaru zmiany konta użytkownika na konto autora wraz z podaniem szeregu danych, m.in. opisu i przykładów dotychczasowej działalności oraz zamierzonych celów. Operator dokonuje weryfikacji danych i podejmuje decyzję o zmianie charakteru konta. Usługi świadczone na rzecz autora, w tym możliwość korzystania przez niego z serwisu, założenie i prowadzenie konta autora oraz usługi płatnicze, mają - co ważne - charakter odpłatny. Wynagrodzenie operatora $\mathrm{w}$ formie prowizji wynosi $6,5 \%$ wsparcia przekazanego każdorazowo na rzecz autora przez tzw. patrona lub mecenasa.

Założeniem funkcjonowania serwisu Patronite jest bowiem przekazywanie autorom ( $w$ rozumieniu regulaminu serwisu) za pośrednictwem serwisu kwot pieniężnych przez innych użytkowników, którzy są określani jako patroni i mecenasi. Użytkownik w ramach serwisu może wybrać jednego autora lub większą ich liczbę oraz zdecydować o chęci wspierania ich działalności poprzez cykliczne, comiesięczne przekazywanie środków pieniężnych. $Z$ kolei mecenas we własnym zakresie i według własnego uznania decyduje, któremu autorowi przekaże wsparcie $\mathrm{w}$ formie darowizny. W zamian za dokonane wsparcie patroni lub mecenasi otrzymują od autora określone świadczenia w formie tzw. progu, który oznacza świadczenia oferowane przez autora na rzecz patrona w zamian za otrzymywane wsparcie (\$ pkt 14 regulaminu).

5. Powyższy (dość skrócony) opis funkcjonowania serwisu internetowego Patronite oraz uprawnień i powinności, które łączą się z posiadaniem na nim konta autora, uwidacznia pewną daleko idącą komplikację, jeśli kwalifikować je ze względu na status posła.

4 https://patronite.pl/jak_to_dziala [dostęp 29 października 2019 r.]. 
W kontekście praw i obowiązków poselskich wstępnie istotne jest następujące ustalenie. Otóż działania podejmowane w ramach korzystania z konta autora mogą - choć nie muszą - stanowić element działalności gospodarczej. Działalnością gospodarczą jest, zgodnie z obowiązującą ustawą z dnia 6 marca 2018 r. - Prawo przedsiębiorców (t.j. Dz.U. 2019, poz. 1292, ze zm.), zorganizowana działalność zarobkowa wykonywana we własnym imieniu i w sposób ciągły. Należy przy tym uwzględnić art. 5 ust. 1 tej ustawy, zgodnie z którym nie stanowi działalności gospodarczej działalność wykonywana przez osobę fizyczną, której przychód należny z tej działalności nie przekracza w żadnym miesiącu 50\% kwoty minimalnego wynagrodzenia, wskazanego w ustawie z dnia 10 października 2002 r. o minimalnym wynagrodzeniu za pracę (t.j. Dz.U. 2018, poz. 2177), i która w okresie ostatnich 60 miesięcy nie wykonywała działalności gospodarczej. Ocena, czy określony autor jest osobą, która prowadzi działalność gospodarczą, wymaga uwzględnienia wielu czynników, nie tylko zarobkowego charakteru i ciągłości określonej działalności, ale również wysokości otrzymanych przychodów, a więc wsparcia w rozumieniu regulaminu serwisu Patronite. Trzeba przy tym zauważyć, że zgodnie z informacjami tegoż serwisu internetowego: „Jeśli za udzielone finansowanie Patron otrzymuje od Ciebie świadczenie wzajemne (np. książkę, płytę, bilet na koncert), to może to być uznane za sprzedaż (przedsprzedaż). W takim przypadku kwoty otrzymane od Patronów należy zaliczyć do przychodów z działalności gospodarczej”5.

Stwierdzenie, że powyżej opisana sytuacja faktycznie zaistniała, oznacza istotne konsekwencje w zakresie zarówno prawa do uposażenia poselskiego, jak i treści oświadczeń majątkowych oraz informacji podawanych przez posła do Rejestru Korzyści. Dalsze rozważania odnoszą się jednak generalnie do sytuacji, gdy korzystanie z serwisu Patronite nie jest elementem (częścią) prowadzenia działalności gospodarczej. Nie ma o tym bowiem mowy w złożonym zleceniu.

\section{Uzasadnienie i ustalenia szczegółowe}

1. Punktem wyjścia do dalszych rozważań jest ogólne założenie, w myśl którego objęcie mandatu poselskiego nie pozbawia posła prawa do korzystania z przysługujących mu konstytucyjnych praw i wolności, w tym również szeroko pojmowanej wolności wyboru i wykonywania zawodu (art. 65 ust. 1 Konstytucji). Jednak z uwagi na zasadę rzetelności działania instytucji publicznych ustawy, a zwłaszcza ustawa o wykonywaniu mandatu posła i senatora, wprowadzają pewne ograniczenia w tym zakresie. Istotne jest założenie, że przepisy ustaw formułujące te ograniczenia mają charakter wyjątkowy, a jako takie - zgodnie z ogólnymi regułami wykładni prawa - nie powinny podlegać wykładni rozszerzającej.

5 https://patronite.freshdesk.com/support/solutions/articles/43000072479-podatki-jak-rozlicza\%C4\%87-si\%C4\%99-ze-wsparcia [dostęp 29 października 2019 r.]. 
Tego rodzaju ograniczenie o charakterze ogólnym zostaje wprowadzone przez przede wszystkim art. 33 ustawy o wykonywaniu mandatu. Zgodnie z ust. 2 tego przepisu posłowie (i senatorowie) nie mogą podejmować dodatkowych zajęć ani otrzymywać darowizn mogących podważyć zaufanie wyborców do wykonywania mandatu zgodnie $\mathrm{z}$ art. 1 ust. 1 ustawy. $Z$ kolei ten ostatni przepis stanowi, że posłowie (i senatorowie) wykonują swój mandat, kierując się dobrem narodu. W tym kontekście można postawić dwa pytania: czy użytkowanie konta autora w serwisie Patronite.pl stanowi dodatkowe zajęcie i czy jest ono niedozwolone jako mogące podważyć zaufanie wyborców?

2. Analizując pierwszy problem, należy zauważyć, że zgodnie z językową wykładnią „zajęcie” to czynność, którą dana osoba „wykonuje z przyjemnością lub jako część swoich codziennych obowiązków"6. Użyte w ustawie pojęcie dodatkowych zajęć nie jest więc precyzyjne. Jasne jest przy tym, że regulacja prawna nie może odnosić się do czynności „wykonywanych z przyjemnością”, ale do drugiej ze słownikowych cech zajęcia. Absurdalna byłaby jednak wykładnia, że wykonywanie zwykłych (typowych) czynności życiowych może być traktowane jako dodatkowe zajęcie $w$ rozumieniu analizowanego przepisu ${ }^{7}$. Jednak $w$ tym miejscu trzeba przytoczyć praktyczną charakterystykę działalności autora zarejestrowanego na serwisie Patronite: „Należy postawić na komunikację bierną czyli np. wrzucać linki do Patronite pod swoimi filmami lub na końcu artykułu blogowego. Jednak trzeba również działać aktywnie, pokazując odbiorcom, że np. udało się osiągnąć pierwszy cel, że udało się zebrać 100 patronów, że jakiś patron pokazał w social mediach prezent, który dostał od autora. To jest nieustająca praca. Zawsze mówimy twórcom, że Patronite nie polega na tym, by odpalić profil i liczyć banknoty - to jest komunikacyjna praca, która wymaga od

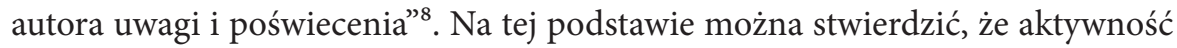
autora w rozumieniu regulaminu serwisu Patronite wymaga, co do zasady, podejmowania wielu różnorodnych, powtarzających się działań, $\mathrm{w}$ tym regularnego zapoznawania się ze stanem konta, a przede wszystkim realizacji zobowiązania do dokonywania świadczeń na rzecz patronów. Nie można wyjątkowo wykluczyć sytuacji, kiedy z informacji umieszczonych na koncie konkretnego autora wynika, że jego aktywność ma wyłącznie okazjonalny i sporadyczny charakter. Jednak wobec zarysowanych wcześniej „społecznościowych” celów serwisu Patronite oraz wyrażonej w jego regulaminie idei crowdfundingu subskrypcyjnego sytuację taką należy uznać za mało prawdopodobną. Trzeba zatem uznać, że

$6 \quad$ Słownik języka polskiego, t. VI, red. M. Bańko, Warszawa 2007, s. 296.

$7 \quad$ W. Odrowąż-Sypniewski, Opinia prawna na temat obowiązków poselskich związanych $z$ członkostwem posła $w$ organizacjach międzynarodowych [w:] Status posła w opiniach Biura Analiz Sejmowych (2007-2015), t. II, cz. 1, Warszawa 2015, s. 497.

$8 \quad$ M. Wujek, Patronite - jedyny w Polsce model crowdfundingu subskrypcyjnego dla twórców, https://marketingibiznes.pl/start-up-zone/patronite-jedyny-w-polsce-model-crowdfundingu-subskrypcyjnego-dla-tworcow [dostęp 28 października 2019 r.]. 
użytkowanie konta autora na portalu Patronite.pl stanowi zasadniczo dodatkowe (w stosunku do wykonywania mandatu parlamentarnego) zajęcie w rozumieniu art. 33 ustawy o wykonywaniu mandatu posła i senatora.

3. Jeśli chodzi o drugie z postawionych wcześniej pytań, to odpowiedź jest uzależniona od przejawów aktywności, jaką podejmuje osoba będąca jednocześnie posłem i autorem w serwisie Patronite, w szczególności treści, jakie byłyby udostępniane w tym serwisie, oraz opisu przedsięwzięć (projektów), jakie autor przedstawia potencjalnym patronom i mecenasom. Należy podkreślić, że nie jest tutaj istotne osobiste, subiektywne przekonanie posła odnośnie do wpływu (możliwości wpływu) na wykonywanie przez niego mandatu parlamentarnego. Istotne są - odbiór takiej działalności przez wyborców i sama możliwość podważenia przynajmniej u pewnej części z nich zaufania do konkretnego posła. Szczególnym przypadkiem podważenia zaufania wyborców jest wykorzystywanie swojej funkcji w celu uzyskania korzyści dla siebie i osób bliskich (art. 3 uchwały Sejmu z dnia 17 lipca 1998 r. - Zasady etyki poselskiej, M.P. nr 24, poz. 338). Mówiąc konkretniej: oznacza to przede wszystkim, że czynności podejmowane w ramach działań autora serwisu Patronite mogą być uważane za mogące podważyć zaufanie wyborców do wykonywania mandatu, jeśli okoliczności wskazują na to, że poseł może uzyskiwać korzyści finansowe w związku z podejmowaniem działań będących wykonywaniem uprawnień i obowiązków poselskich (np. interwencji poselskich) lub też zajmowaniem w toku prac Sejmu (np. w wypowiedziach na posiedzeniach plenarnych lub posiedzeniach komisji sejmowych, w interpelacjach i zapytaniach poselskich) określonego stanowiska. Nawiązywanie w materiałach udostępnionych na portalu Patronite (w szczególności w opisie planowanych przedsięwzięć) do działalności poselskiej należy uznać za prawnie niedopuszczalne (zob. niżej pkt 4).

4. Status autora na portalu Patronite wiąże się również z możliwością otrzymywania za jego pośrednictwem darowizn od wspomnianych wcześniej mecenasów. Ustawa o wykonywaniu mandatu nie zabrania posłom przyjmowania darowizn, ale - jak wspomniano - nie mogą one rodzić wątpliwości co do motywacji posłów w wykonywaniu mandatu. Stąd też wymóg należytej i daleko idącej staranności oznacza w tym przypadku powinność posła dokonywania ocen poszczególnych darowizn, również jeśli chodzi o osobę darczyńcy i ewentualny pośredni (np. czasowy) ich związek z działalnością parlamentarną autora, który korzysta ze swojego konta na serwisie Patronite. Przy ocenie przestrzegania art. 33 ust. 2 nie można ograniczać się do ściśle formalistycznego podejścia.

Pewien problem rodzi tutaj $\$ 7$ pkt 12 regulaminu serwisu, zgodnie z którym „[u]zyskanie statusu Autora oznacza zgodę Autora na otrzymywanie od Mecenasa Wsparcia w formie darowizny”, oraz $\$ 10$, w myśl którego „do zawarcia umowy darowizny pomiędzy Mecenasem oraz Autorem dochodzi z chwilą uznania rachunku bankowego Autora”. Wspomniana wcześniej zgoda dotyczy na pierwszy rzut oka wszystkich darowizn otrzymywanych za pośrednictwem serwisu, 
a z $\$ 10$ wynika domniemana ogólna zgoda autora na ich przyjmowanie. Jednak $\mathrm{z}$ drugiej strony regulamin serwisu wyraźnie zastrzega, że w jego ramach niedozwolone jest m.in.: korzystanie z serwisu w sposób naruszający bądź zmierzający do naruszenia obowiązujących przepisów prawa ( $\$ 4$ pkt a).

Należy więc stwierdzić, że jeżeli przyjęcie darowizny (a ta w świetle prawa cywilnego jest umową, wymaga zatem oświadczenia zarówno darczyńcy, jak i obdarowanego - art. $888 \$ 1$ Kodeksu cywilnego) stałoby w sprzeczności art. 33 ust. 2 ustawy o wykonywaniu mandatu, to działanie takie naruszałoby obowiązujące ustawy (i postanowienia regulaminu serwisu Patronite). Stąd też poseł powinien $\mathrm{w}$ takiej sytuacji niezwłocznie dokonać zwrotu darczyńcy tej kwoty, aby uniknąć zarzutu naruszenia prawa.

Należy podkreślić, że aktywność posła (również w formach elektronicznych) podlega ograniczeniom, wynikającym $\mathrm{z}$ art. 33 ust. 3 ustawy o wykonywaniu mandatu, w myśl którego: „Posłowie i senatorowie nie mogą powoływać się na swój mandat ani posługiwać tytułem posła lub senatora w związku z podjętymi dodatkowymi zajęciami bądź działalnością gospodarczą prowadzoną na własny rachunek lub wspólnie z innymi osobami”. Oznacza to, że wyraźne powołanie się lub samo podanie swojego statusu jako posła na Sejm w związku z działaniami podjętymi w roli autora na serwisie Patronite (np. pośrednio poprzez odwołanie do wystąpienia na posiedzeniu Sejmu lub komisji sejmowej, treści zgłoszonej interpelacji lub zapytania poselskiego czy też link strony Sejmu) należy traktować jako naruszenie ustawy o wykonywaniu mandatu posła i senatora.

5. Podsumowując tę część rozważań, należy stwierdzić, że z przepisów ustawy o wykonywaniu mandatu posła i senatora nie wynika zakaz podjęcia i prowadzenia działalności autora na portalu internetowym Patronite. Jednak działalność ta podlega istotnym ograniczeniom, przede wszystkim w zakresie podawanych do publicznej wiadomości opisów dotychczasowej działalności (osiągnięć) oraz wskazywania projektów (przedsięwzięć), z którymi jest związane wsparcie patronów i mecenasów tego portalu, jak również przyjmowania darowizn (wsparcia finansowego).

6. Zgodnie $\mathrm{z}$ art. 33 ust. 1 ustawy o wykonywaniu mandatu poseł jest zobowiązany powiadomić odpowiednio Marszałka Sejmu o zamiarze podjęcia dodatkowych zajęć, z wyjątkiem działalności podlegającej prawu autorskiemu i prawom pokrewnym. Jak już wcześniej była mowa, działalność autora w rozumieniu regulaminu serwisu Patronite to zasadniczo dodatkowe (w stosunku do wykonywania funkcji parlamentarzysty) zajęcie w rozumieniu ustawy poselsko-senatorskiej.

Należy zaznaczyć, że odstępstwo wskazane w końcowej części powołanego przepisu ma charakter wyjątku, a zatem nie powinno być interpretowane w sposób rozszerzający. Oznacza to, że - ujmując rzecz lapidarnie - tylko działalność podlegająca $\mathrm{w}$ całości prawu autorskiemu (i prawom pokrewnym) powoduje wyłączenie z obowiązku informacyjnego. Jeżeli zaś w jakiejś działalności posła 
są tylko pewne elementy (fragmenty) podlegające prawu autorskiemu, to aktywność ta traktowana jako pewna całość podlega obowiązkowi zgłoszenia.

Pojęcie działalności podlegającej prawu autorskiemu i prawom pokrewnym nawiązuje do przepisów ustawy z dnia 4 lutego 1994 r. o prawie autorskim i prawach pokrewnych (t.j. Dz.U. 2019, poz. 1231). Nie wnikając w szczegóły, należy stwierdzić, że ustawa ta stanowi przede wszystkim, że przedmiotem prawa autorskiego jest każdy przejaw działalności twórczej o indywidualnym charakterze, ustalony w jakiejkolwiek postaci, niezależnie od wartości, przeznaczenia i sposobu wyrażenia (utwór). W szczególności przedmiotem prawa autorskiego są m.in. utwory: sceniczne, sceniczno-muzyczne, choreograficzne i pantomimiczne oraz audiowizualne (w tym filmowe). Zgodnie $\mathrm{z}$ art. 1 ust. 3 powołanej ustawy utwór jest przedmiotem prawa autorskiego od chwili ustalenia, chociażby miał postać nieukończoną.

Z przepisów tych wynika przede wszystkim, że sam proces powstawania utworu (do momentu ustalenia choćby wstępnej jego postaci) nie jest objęty regulacją wspomnianej ustawy. Nie reguluje ona również problematyki finansowania (pokrywania kosztów) powstania utworu. Poza tym działalność podlegająca prawu autorskiego winna być rozumiana przez pryzmat wykonywania określonych w ustawie praw autorskich, zwłaszcza praw o naturze majątkowej. W tym zakresie należy wspomnieć, że - zgodnie z art. 16 prawa autorskiego - jeżeli ustawa nie stanowi inaczej, autorskie prawa osobiste chronią nieograniczoną w czasie i niepodlegającą zrzeczeniu się lub zbyciu więź twórcy z utworem, a w szczególności prawo do: autorstwa utworu; oznaczenia utworu swoim nazwiskiem lub pseudonimem albo do udostępniania go anonimowo; nienaruszalności treści i formy utworu oraz jego rzetelnego wykorzystania; decydowania o pierwszym udostępnieniu utworu publiczności; nadzoru nad sposobem korzystania z utworu. Z kolei w myśl art. 17 twórcy przysługuje wyłączne prawo do korzystania z utworu i rozporządzania nim na wszystkich polach eksploatacji oraz do wynagrodzenia za korzystanie $\mathrm{z}$ utworu, o ile ustawa nie stanowi inaczej.

Ujmując cały problem w nieco inny sposób, trzeba stwierdzić, że działalność podlegającą prawu autorskiemu i prawom pokrewnym należy rozumieć głównie jako związaną ze sposobem korzystania z praw autorskich do konkretnego utworu. Pojęcie to nie obejmuje samego procesu tworzenia utworu, a w szczególności kwestii finansowania tego rodzaju działalności. Należy tu dodać, że serwis Patronite może „promować” również działalność, która w ogóle nie jest objęta prawami autorskimi, w regulaminie mowa bowiem o działalności sportowej, społecznej lub każdym innym przejawie działalności autora.

Istotnie niektóre aspekty aktywności autora na portalu Patronite podlegają prawu autorskiemu. Tytułem przykładu zgodnie z regulaminem: „Z chwilą zamieszczenia przez Autora w Serwisie Materiałów podlegających ochronie jako przedmiot prawa autorskiego Autor udziela Operatorowi bezpłatnej, niewyłącznej, nieograniczonej czasowo i terytorialnie licencji na wykorzystanie ich w celu 
świadczenia Usług i dostarczania funkcjonalności Serwisu, jak również, w celach marketingu i promocji działalności Serwisu oraz Działalności Autora - poprzez publiczne udostępnianie ww. Materiałów w Serwisie w taki sposób, aby każdy mógł mieć do nich dostęp w miejscu i czasie przez siebie wybranym” ( $\$ 3$ ust. 6). Ponadto: „Autor każdorazowo publikując Materiały, w szczególności projekty zamierzonych celów związanych z jego Działalnością, propozycje, pomysły lub działania oraz propozycje zawartości Progów składa oświadczenie dotyczące zakresu praw autorskich przysługujących mu do publikowanych Materiałów w tym zawartości Progów” (\$8 ust. 2).

Działania autora obejmują jednak o wiele większy zakres. Wraz z założeniem konta autora powstają po jego stronie inne powinności związane przede wszystkim z przepływem środków finansowych oraz realizacją świadczeń wobec tzw. patronów. Tę część aktywności autora trudno uznać za działalność podlegającą w całości prawu autorskiemu i prawom pokrewnym. Świadczenia oferowane przez autora na rzecz patronów w zamian za otrzymywane wsparcie nie muszą łączyć się wykonywaniem praw autorskich do konkretnego utworu. W praktyce podane przez autora określenie tzw. progów powoduje powstanie zobowiązań do świadczeń rzeczowych (np. prezentu w postaci koszulki), osobistych (np. spotkania się/spotkań z patronem), majątkowych (np. bezpłatnych biletów na imprezę $\mathrm{z}$ udziałem autora).

Powoduje to, że całokształt aktywności autora w serwisie Patronite trudno byłoby uznać za działalność podlegającą (w całości) prawu autorskiemu i że tym samym nie podlegałaby ona obowiązkowi, o którym mowa w art. 33 ust. 1 ustawy o wykonywaniu mandatu.

7. Jeśli chodzi o zagadnienie uposażenia poselskiego, to kwestia nie jest w pełni jednoznaczna. Podstawą oceny jest w tym przypadku art. 25 ust. 1 ustawy o wykonywaniu mandatu, zgodnie z którym: „Posłom i senatorom w okresie sprawowania mandatu, licząc od pierwszego posiedzenia Sejmu lub Senatu, przysługuje uposażenie poselskie lub senatorskie, zwane dalej «uposażeniem», wypłacane miesięcznie, także za niepełne miesiące sprawowania mandatu”. Prawo do uposażenia jest jednak ograniczone przez art. 25 ust. 3 ustawy, który stanowi: „Posłowi lub senatorowi, który nie korzysta z urlopu bezpłatnego, o którym mowa w art. 29 ust. 1, albo prowadzi działalność gospodarczą samodzielnie lub wspólnie z innymi osobami, albo nie zawiesił prawa do emerytury lub renty, uposażenie, o którym mowa w ust. 1 i 2, nie przysługuje, z zastrzeżeniem ust. 3a”.

Dodatkowo istotna jest treść art. 25 ust. 4, zgodnie z którym: „W uzasadnionych przypadkach Prezydium Sejmu lub Prezydium Senatu może podjąć decyzję o przyznaniu, na wniosek posła lub senatora, o którym mowa w ust. 3, uposażenia w całości lub w części”.

W tym świetle wydawałoby się, że działalność autora w serwisie Patronite nie wpływa na prawo do uposażenia, o ile nie jest to częścią jego działalności gospodarczej. Jednak stan prawny jest w tej materii nieco bardziej skompliko- 
wany, zgodnie bowiem ze wspomnianą wcześniej uchwałą Prezydium Sejmu z 25 września 2001 r. (załącznik nr 1) poseł ubiegający się o wypłacanie mu zgodnie z art. 25 ust. 1 ustawy - uposażenia jest zobowiązany złożyć wniosek, w którym oświadcza, że nie prowadzi żadnej aktywności pozaparlamentarnej i nie uzyskuje jakichkolwiek dochodów z tego tytułu (pkt 2 wniosku). W drodze wyjątku nie dotyczy to posłów prowadzących działalność podlegającą prawu autorskiemu i prawom pokrewnym. Nie wnikając tu w skomplikowaną prawnie kwestię, czy uchwała Prezydium Sejmu nie wykracza poza granice upoważnienia ustawowego wynikającego $\mathrm{z}$ art. 25 ust. 6 ustawy o wykonywaniu mandatu, należy stwierdzić, że - zgodnie z wcześniejszymi ustaleniami - działalność autora zarejestrowanego w serwisie Patronite należy traktować jako aktywność pozaparlamentarną. Poseł ją wykonujący nie powinien więc podpisać takiego wniosku szczególnie w sytuacji, gdy jako autor faktycznie otrzymał wsparcie finansowe, stanowiące jego dochód (w rozumieniu podatkowym). Jest to tym bardziej wykluczone, ponieważ wniosek w sprawie wypłaty uposażenia poselskiego powinien być zgodny z danymi zawartymi w składanych oświadczeniach o stanie majątkowym oraz w Rejestrze Korzyści (zob. niżej pkt 8 i 9).

W takiej sytuacji posłowi pozostaje możliwość złożenia wniosku o wypłatę uposażenia w trybie art. 25 ust. 4 ustawy ze wskazaniem, że prowadzi aktywność pozaparlamentarną o stałym charakterze i uzyskał z tego tytułu w określonym okresie dochód we wskazanej kwocie. Jednak w tej sytuacji przyznanie uposażenia (w części lub całości) zależy od decyzji Prezydium Sejmu.

8. Stosunkowo prosta (na tle wcześniejszych ustaleń) wydaje się odpowiedź na trzecie pytanie dotyczące uwzględnienia przez posła użytkownika i autora w serwisie Patronite tego faktu w Rejestrze Korzyści, aczkolwiek i tu pojawiają się pewne wątpliwości. Zgodnie bowiem z art. 35a ust. 3 ustawy o wykonywaniu mandatu do Rejestru tego należy zgłaszać m.in. informacje o:

„1) wszystkich stanowiskach i zajęciach wykonywanych zarówno w administracji publicznej, jak i w instytucjach prywatnych, z tytułu których pobiera się wynagrodzenie, oraz pracy zawodowej wykonywanej na własny rachunek;

2) faktach materialnego wspierania działalności publicznej prowadzonej przez zgłaszającego;

3) darowiźnie otrzymanej od podmiotów krajowych lub zagranicznych, jeżeli jej wartość przekracza 50\% najniższego wynagrodzenia pracowników za pracę, obowiązującego w grudniu roku poprzedzającego, określonego przez Ministra Pracy i Polityki Socjalnej na podstawie Kodeksu pracy”.

Należy podkreślić, że przepis ten - w odróżnieniu od niektórych wcześniej omówionych regulacji - obejmuje również zajęcia i pracę „podlegającą prawu autorskiemu i prawom pokrewnym”. Odnośnie do punktu pierwszego trzeba zauważyć, że z tytułu zarejestrowania się jako autor na portalu Patronite nie pobiera się żadnego wynagrodzenia lub analogicznych świadczeń od operatora, nie trzeba zatem zgłaszać tego faktu do Rejestru Korzyści. Jednakże należy zauważyć, 
że fakt ten może być powiązany z działalnością twórczą, artystyczną, kulturalną lub społeczną, która stanowi pracę zawodową wykonywaną na własny rachunek w rozumieniu art. 35a ust. 3 pkt 1 ustawy. W tym kontekście praca zawodowa to względnie stale wykonywane zajęcie, wymagające wcześniejszego przygotowania (nie jednorazowa lub sporadyczna aktywność), wykonywane w celach zarobkowych i stanowiące wyłączne lub istotne źródło utrzymania określonej osoby. Nie zmienia to faktu, że same działania podejmowane w ramach statusu autora serwisu Patronite trudno traktować jako pracę zawodową.

Odnośnie do zastosowania pkt 2 art. 35a ust. 1 ustawy o wykonywaniu mandatu, to regulamin serwisu Patronite określa kwoty przekazywane na rzecz autorów mianem wsparcia, a pojęcie to zostało zdefiniowane jako „środki pieniężne przekazywane przez Patrona lub Mecenasa Autorowi, przeznaczone na jego działalność” (\$1 pkt 26). Należy również przyjąć, że podawanie na swojej stronie internetowej w powszechnie dostępnym serwisie Patronite informacji o dotychczasowych osiągnięciach czy planowanych przedsięwzięciach czyni tę aktywność działalnością publiczną. Oznacza to, że wsparcie, o jakim mówi regulamin serwisu Patronite, podlega regulacji zawartej w art. 35a ust. 1 pkt 2 ustawy o wykonywaniu mandatu.

Jeśli chodzi o świadczenia ze strony tzw. mecenasa, to zgodnie z regulaminem portalu Patronite powinny one, co do zasady, stanowić darowizny, „ponieważ nie są związane z żadnym świadczeniem wzajemnym autora na rzecz wspierającego go Mecenasa"9 . Stanowisko to uznać należy za trafne, stąd darowizny takie podlegają zgłoszeniu w Rejestrze Korzyści, o ile przekraczają wskazaną wcześniej kwotę.

Powstaje tu pewien problem natury formalnej, polegający na tym, że wsparcie patrona może mieć różny charakter prawny. Z wyjaśnień dla autorów, które zamieszczono na portalu Patronite, wynika bowiem: „Jeżeli jesteś osobą nieprowadzącą działalności gospodarczej i Patron za udzielone finansowanie otrzymuje od Ciebie jedynie podziękowania (np. umieszczenie na liście wspierających, list, e-mail) lub symboliczny upominek (gadżet, link do ciekawej strony, kartkę pocztową z Twoją grafiką), to otrzymane wsparcie powinno zostać uznane za darowiznę"10. Również to stwierdzenie należy uznać za prawidłowe. Oznacza to, że wpisy w Rejestrze Korzyści nie powinny być ograniczone tylko do darowizn pochodzących od mecenasów, ale w opisanych powyżej sytuacjach powinny obejmować także wpłaty patronów.

9. Zgodnie $\mathrm{z}$ art. 35 ust. 1 ustawy o wykonywaniu mandatu posłowie i senatorowie są obowiązani do złożenia oświadczenia o swoim stanie majątkowym. Oświadczenie to powinno zawierać w szczególności informacje o:

9 https://patronite.freshdesk.com/support/solutions/articles/43000072479-podatki-jak-rozlicza\%C4\%87-si\%C4\%99-ze-wsparcia [dostęp 20 października 2019 r.].

10 https://patronite.freshdesk.com/support/solutions/articles/43000072479-podatki-jak-rozlicza\%C4\%87-si\%C4\%99-ze-wsparcia [dostęp 31 października 2019 r.]. 
„1) zasobach pieniężnych, nieruchomościach, uczestnictwie w spółkach cywilnych lub w osobowych spółkach handlowych, udziałach i akcjach w spółkach handlowych, o nabytym od Skarbu Państwa, innej państwowej osoby prawnej, jednostek samorządu terytorialnego, ich związków lub komunalnej osoby prawnej, mieniu, które podlegało zbyciu w drodze przetargu, a także o prowadzonej działalności gospodarczej i stanowiskach zajmowanych w spółkach handlowych;

2) dochodach osiąganych $z$ tytułu zatrudnienia lub innej działalności zarobkowej lub zajęć, z podaniem kwot uzyskiwanych z każdego tytułu”.

O ile poseł nie prowadzi działalności gospodarczej, to fakt zarejestrowania się w charakterze autora w serwisie Patronite nie podlega przepisom pkt 1 .

Natomiast jeśli chodzi o otrzymane świadczenia finansowe, to kwoty pochodzące od patronów (chyba że w istocie stanowią darowizny - zob. wyżej pkt 8) należałoby traktować jako dochody osiągane z tytułu innej działalności zarobkowej lub zajęć i wykazywać w punkcie IX oświadczenia majątkowego, z podaniem ogólnej kwoty uzyskiwanej z tego tytułu. Należy tylko podkreślić, że dochód nie oznacza kwoty otrzymanych za pośrednictwem serwisu Patronite wpłat. Nie wnikając w szczegóły, ogólnie należy stwierdzić, że przez dochody rozumie się tzw. przychody pomniejszone o koszty ich uzyskania. W związku ze skomplikowanymi regulacjami podatkowymi dotyczącymi tego zagadnienia jego bliższa analiza w tym miejscu nie jest możliwa bez odniesienia do konkretnej sytuacji.

\section{Podsumowanie}

- Działalność podejmowana w związku ze statusem autora w rozumieniu postanowień regulaminu serwisu internetowego Patronite stanowi, co do zasady, dodatkowe zajęcie posła, o którym mowa w art. 33 ust. 1 i 2 ustawy o wykonywaniu mandatu posła i senatora. Podlega zatem obowiązkowi zawiadomienia Marszałka Sejmu. Nie jest ona rodzajem aktywności pozaparlamentarnej posłów, który byłby zabroniony przez obowiązujące przepisy, aczkolwiek wprowadzają one w tym zakresie pewne ograniczenia i konsekwencje dotyczące świadczeń poselskich oraz obowiązki informacyjne po stronie posła.

- W związku z przepisami uchwały Prezydium Sejmu z dnia 25 września 2001 r. w sprawie szczegółowych zasad i trybu wypłacania uposażenia poselskiego oraz odprawy parlamentarnej należy stwierdzić, że wszystkie działania posła będącego autorem w serwisie Patronite stanowią aktywność pozaparlamentarną, która tylko częściowo podlega prawu autorskiemu i prawom pokrewnym, a zatem oddziałuje na uprawnienie posła do otrzymywania uposażenia poselskiego.

- Dochody, inne korzyści majątkowe i darowizny, które autor zarejestrowany w serwisie Patronite będący jednocześnie posłem otrzymuje od patronów i mecenasów tego serwisu, podlegają ujawnieniu w oświadczeniu o stanie majątkowym (w punkcie IX), a także odpowiedniemu zgłoszeniu do Rejestru Korzyści. 
Dochody te należy rozumieć zgodnie z przepisami podatkowymi (a więc nie należy utożsamiać ich z tzw. przychodami i trzeba uwzględniać koszty uzyskania głównie prowizję operatora serwisu).

- Czynności podejmowane w ramach działań autora serwisu Patronite mogą być uważane za mogące podważyć zaufanie wyborców do wykonywania mandatu, jeśli konkretne okoliczności wskazują, że poseł może uzyskiwać korzyści finansowe w związku z podejmowaniem działań będących wykonywaniem uprawnień i obowiązków poselskich lub też zajmowaniem w toku prac Sejmu (np. w wypowiedziach na posiedzeniach plenarnych lub posiedzeniach komisji sejmowych, $\mathrm{w}$ interpelacjach i zapytaniach poselskich) określonego stanowiska. W ramach działań wynikających ze statusu autora serwisu Patronite poseł nie może bezpośrednio lub pośrednio powoływać się na swój mandat parlamentarny oraz posługiwać się tytułem posła.

- W kontekście postawionych w zleceniu pytań przepisy ustawy o wykonywaniu mandatu posła i senatora wymagałyby pewnych zmian w celu bardziej jednoznacznego uregulowania niezwykle różnorodnej potencjalnej aktywności posłów z wykorzystaniem form elektronicznych.

\section{Bibliografia}

Odrowąż-Sypniewski W., Opinia prawna na temat obowiązków poselskich związanych $z$ członkostwem posła $w$ organizacjach międzynarodowych [w:] Status posła w opiniach Biura Analiz Sejmowych (2007-2015), t. II, cz. 1, Warszawa 2015.

Słownik języka polskiego, t. VI, red. M. Bańko, Warszawa 2007.

Wujek M., Patronite - jedyny w Polsce model crowdfundingu subskrypcyjnego dla twórców, https://marketingibiznes.pl/start-up-zone/patronite-jedyny-w-polsce-model-crowdfundingu-subskrypcyjnego-dla-tworcow [dostęp 28 października 2019 r.]. 